Maurer School of Law: Indiana University

Fall 2006

\title{
Regulating the Commander in Chief: Some Theories
}

\author{
Saikrishna Prakash \\ University of San Diego School of Law
}

Follow this and additional works at: https://www.repository.law.indiana.edu/ilj

Part of the Constitutional Law Commons, Law and Politics Commons, Legislation Commons, and the Military, War, and Peace Commons

\section{Recommended Citation}

Prakash, Saikrishna (2006) "Regulating the Commander in Chief: Some Theories," Indiana Law Journal: Vol. 81 : Iss. 4 , Article 8.

Available at: https://www.repository.law.indiana.edu/ilj/vol81/iss4/8

This Symposium is brought to you for free and open access by the Law School Journals at Digital Repository @ Maurer Law. It has been accepted for inclusion in Indiana Law Journal by an authorized editor of Digital Repository@ Maurer Law. For more information, please contact rvaughan@indiana.edu.

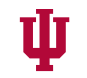

JEROME HALL LAW LIBRARY

INDIANA UNIVERSITY

Maurer School of Law
Bloomington 


\title{
Regulating the Commander in Chief: Some Theories
}

\author{
SAIKRISHNA PRAKASH
}

Recent events have caused scholars to consider a long ignored issue: the relation between the commander in chief $(\mathrm{CINC})^{1}$ and Congress's powers to regulate the armed forces and captures. ${ }^{2}$ The famous Bybee memorandum brought this issue to the fore when it asserted that Congress could not interfere with "the President's direction of such core war matters such as the detention and interrogation of enemy combatants."3 The memo's critics scoffed at this claim, insisting that Congress may regulate the detention of enemy soldiers. With their articles in this issue, Dean Harold Koh, Neil Kinkopf, and others have added their voices to the clamor against the Bybee memo.

Read in isolation, the Constitution's text does not detail the scope of presidential and congressional powers over the conduct of a war. Notwithstanding its relative emptiness, both sides of this issue seem content to make arguments that rely almost exclusively on the text. As a result, both sides have chosen to make textual claims that largely beg the question. In this war of words, the opposing parties are firing blanks.

To advance a properly grounded answer, one must come to grips with English and American history relating to commander in chief authority and the powers to regulate the armed forces and captures. In the late eighteenth century, what did it mean to be a commander in chief? What did it mean to regulate the armed forces and captures on land and water? (E.g., does "captures" refer to armaments, soldiers, land, or some combination?) Not having conducted this research, I will neither defend the constitutional arguments found in the Bybee memo nor join the legions who have contested its conclusions.

Of course, having sidestepped precisely what is desperately needed, perhaps very little else should be said. Nonetheless, this brief essay describes how the various powers related to the conduct of a war might interact. Hopefully some systematizing in

* Herzog Research Professor of Law, University of San Diego School of Law. Thanks to Dawn Johnsen and the American Constitution Society for inviting me to participate in the Symposium. Thanks to Mike Paulsen and Mike Ramsey for comments.

1. It might seem that the Constitution grants the President a military title-"commander in chief"- and not a power. See U.S. CoNST. art. II, § 2 ("The President shall be Commander in Chief of the Army and Navy ...."). Nonetheless, one cannot be a true commander in chief unless one has certain powers. Hence many suppose that the Constitution implicitly grants powers to the President when it makes him commander in chief. Others suppose that the Commander-in-Chief Clause merely removes all doubts that the President has military authority that has arguably been conveyed by the grant of executive power. See id. $\$ 1$ ("The executive Power shall be vested in a President of the United States of America."). For discussions of why the grant of executive power conveys actual power to the President, see Saikrishna Prakash, The Essential Meaning of Executive Power, 2003 U. ILL. L. REv. 701 (2003); Saikrishna Prakash \& Michael Ramsey, The Executive Power over Foreign Affairs, 111 YALE L.J. 231 (2001).

2. See U.S. ConsT. art. I, $\S 8$, cls. $11,14$.

3. Memorandum for Alberto Gonzales Re: Standards of Conduct for Interrogation under 18 U.S.C. $\$ \S 2340-2340 \mathrm{~A}$, at 31 (Aug. 1, 2002), http://www.washingtonpost.com/wpsrv/nation/documents/dojinterrogationmemo20020801.pdf [hereinafter Memorandum]. 
this area may make it easier for the next scholar to make sense of seemingly opaque text.

Although one might generate any number of theories about the interaction of the Commander in Chief Clause and Congress's war regulatory powers, four seem most plausible. This essay sketches these theories with sufficiently broad strokes that none of these sketches will satisfactorily answer questions about who may regulate certain aspects of a war. In particular, these theories will tell us nothing about whether the Bybee memo or its critics have the better argument about whether Congress can limit the CINC's ability to order coercive interrogation techniques.

First, it is possible to suppose that congressional and presidential powers do not overlap at all. This "Separation Thesis" might be true because no one in the eighteenth century would have understood the commander in chief authority and the power to regulate the armed forces and captures to ever intersect. They might have been regarded as distinct powers, just as the power to establish post roads and the power to pardon might not be thought to overlap at all. Alternatively, they might be separate powers because the Constitution carves out regulatory authority from the CINC power, such that the President does not have any power to regulate the armed forces or captures. In the absence of express congressional authority, the President might have been able to regulate the armed forces and captures pursuant to his authority as CINC. But the express grants of authority to Congress are meant to be exclusive grants that the President cannot simultaneously enjoy. If the Bybee memo implicitly adopted the Separation Thesis, it must have assumed that regulating the use of torture was neither a regulation of the armed forces nor a regulation of captures. Not being either, the President could use his CINC authority to establish interrogation techniques.

By itself, the Separation Thesis tells us nothing about who may exercise a particular authority. People can agree with this theory and yet disagree about its implications in any particular case. The Bybee memo seems to adopt the view that the power to regulate torture is an exclusive power derivable from the President's role as CINC. ${ }^{4} \mathrm{On}$ the other hand, one could suppose that regulation of torture is a regulation of the armed forces or amounts to a regulation of captures, in which case the Separation Thesis posits that the President has absolutely no power in this area.

This Separation Thesis would pose a practical problem should Congress decline to regulate the armed forces or captures. For instance, if Congress never regulates the armed forces, the President could not step into the breach and unilaterally regulate those forces himself. Similarly, if Congress does not regulate captures, there can be no regulation of captures, for under the Separation Thesis the President cannot regulate captures in the least. Of course, there is the mirror problem. Should the President abdicate his responsibilities as CINC during wartime, Congress could neither act as a plural CINC nor appoint an ersatz CINC to make decisions committed to the actual CINC. 5

A second thesis (the Coterminous Thesis) posits that the powers are coterminous, or at least largely so. The power to act as commander in chief includes a power to regulate soldiers and captures, while the power to regulate soldiers and captures

4. See Memorandum, supra note 3, at 31 .

5. This paragraph's discussion is premised on the notion that the President and Congress cannot delegate their own powers. If each can delegate its own powers, some of these consequences are greatly mitigated. 
likewise includes all the powers associated with being commander in chief. If the powers are coterminous, it naturally invites the question of whose rules will govern when there is a conflict. Although it is possible to suppose that the President's rules always take precedence, or that the last-in-time rule trumps, it surely is far more likely that Congress's rules should trump whenever there is a conflict. The conclusion that congressional statutes trump executive regulation is hardly unique to war powers. Congress likely has the ability to prescribe the manner in which the President executes the law. Nonetheless, when Congress chooses not to do so, the President has a constitutional right to fill in those law execution gaps (this right arises from the grant of executive power and his associated role as chief executive). ${ }^{6}$ The President's law execution power is defeasible in the same way the President's CINC power might be when it comes to regulation of troops and captures: the President has his way until Congress speaks to the contrary.

In a system of overlapping powers, there is an ever-present question of preemption. There would also be the related and difficult question of whether congressional regulation actually conflicts with presidential regulation. Justice Robert Jackson famously wrote of the difficulties of deciding whether Congress had approved or disapproved of presidential actions in war and foreign affairs. ${ }^{7}$ Just as we ask whether Congress has field-preempted some area of state law, we might have to inquire whether some congressional regulation of the armed forces field-preempted some executive regulation.

A third possibility is what we might call the Partial Overlap. It is possible to suppose that the two powers overlap in some ways, ${ }^{8}$ but that each also has an exclusive sphere. While the President might have some authority to regulate the armed forces by virtue of his CINC power, it is possible to suppose that he does not have all the power that Congress has. It would follow that some aspects of the powers to regulate the armed forces and captures are exclusive to Congress. For instance, while the President might create training rules that he could enforce via removal, ${ }^{9}$ perhaps he could not go further and imprison a soldier for failing to follow them. On the other hand, Congress might both create training rules and provide for the punishment of those who flout the rules.

Likewise, Congress would have some authority over aspects of the CINC power, but there would be other CINC aspects that Congress could not reach despite its authority to regulate the armed forces and captures. Many scholars clearly believe that the President has some exclusive CINC power because they admit that Congress cannot regulate tactical decisions involving the retreat and advance of soldiers. Others might suppose that Congress cannot regulate the deployment of military hardware.

6. See Saikrishna Prakash, Regulating Presidential Powers, 91 CORNeuL L. Rev. 215, 249 (2005) (book review).

7. See Youngstown Sheet \& Tube Co. v. Sawyer, 343 U.S. 579, 635 (1952) (Jackson, J., concurring).

8. For reasons discussed earlier, one might suppose that when congressional and presidential powers overlap, congressional rules trump contrary presidential ones in certain areas. See supra text accompanying note 4 .

9. For a discussion of the President's power to remove, see Saikrishna Parkash, Removal and Tenure in Office, 92 VA. L. REv. (forthcoming Dec. 2006). 
The final theory posits that the President has all the powers that Congress has and more, but when Congress acts in its more limited sphere, its rules always trump the President's. As suggested earlier, when Congress's regulations conflict with presidential rules on the armed forces and captures, congressional regulations trump the President's. At the same time, the President has certain exclusive authorities that derive from his role as CINC (such as the sole power to set battlefield tactics). Presumably, these authorities are exclusive because these CINC-derived powers do not constitute or involve regulation of armed forces or of captures. If these powers do not concern the regulation of armed forces or captures, then the Congress clearly cannot have any claim over them.

This last thesis seems the most plausible. First, it makes good sense to suppose that congressional inaction would not generate regulatory paralysis, since even in the absence of congressional regulation, the President could regulate the armed forces on his own. As commander in chief, the President may command-regulate, if you willthe troops in any number of ways. Although the President likely could not regulate captures made by private citizens, perhaps he could regulate captures by the armed forces. Second, it is consistent with the notion that there are some things that Congress cannot do, such as set battlefield tactics.

Ironically, it is possible to read the Bybee memo and its criticisms as both endorsing the last thesis. The Bybee memo says nothing about congressional power. Nonetheless, there would have been no need to refer to certain powers as being "core" powers (as the memo did $^{10}$ ) unless others could be regarded as peripheral. And if the core is unregulable (as the memo clearly argues ${ }^{11}$ ), it might very well be that the periphery is regulable. Hence the Bybee memo could be read as implicitly suggesting that while Congress cannot trump core CINC powers over the treatment of enemy soldiers, Congress could trump certain peripheral CINC powers. ${ }^{12}$

Similarly, the critics of the Bybee memo maintain that while the President has some exclusive authority over tactical decisions involving the advance and retreat of soldiers, he has no such authority over the interrogation of enemy soldiers. Given that critics of the Bybee memo seem opposed to any claim that the President's CINC powers are entirely exclusive but nonetheless admit that some powers are exclusively the President's, it seems quite possible that the critics have adopted the last thesis.

The very fact that both the Bybee memo and its critics might have the same general theory about the Constitution points to interesting possibilities. There may be far less that separates the two sides than they suppose (or that they would care to admit). For instance, if one takes the view that the President must have tactical control of a battlefield, ${ }^{13}$ it is not too far a leap to the conclusion that he may order the torture of

10. See Memorandum, supra note 3 , at 38 .

11. See id. at 38-39.

12. The very idea of an unregulable "core" naturally invites questions about a regulable "periphery."

13. Although the notion that the President must have exclusive tactical control of the movement of forces on a battlefield seems near universal, there is nothing obvious about it. If Congress can order the shifting of troops in times of relative peace (think of the closure of military bases), it is not obvious why Congress could not order the battlefield retreat of soldiers. Whether or not we are at war, one might seem a regulation of soldiers as much as the other. Moreover, the President is CINC whether we are at war or not, and the text of the Constitution 
enemy soldiers. Indeed, the Bybee memo traded on the widespread notion that the President must control tactics on a battlefield when it suggested that he may also order coercive interrogation techniques. ${ }^{14}$ The critics of the Bybee memo have never reconciled their ready willingness to concede that the President has the sole authority to make tactical battlefield decisions with their unremitting hostility to the Bybee memo's view that Congress cannot regulate the interrogation of enemy soldiers. Perhaps this is so because they suppose that coercive techniques will occur far from the battlefield. But this just assumes away the obvious question: what if the President orders the use of coercive techniques on the battlefield? If the President has the sole authority over battlefield advances and retreats, why does he lack the sole authority over battlefield interrogations?

The same argument can be made against the authors of the Bybee memo. Had the Bybee memo discussed where congressional power begins and ends, the obvious issue would have been why Congress could regulate $x$ or $y$ (however far the authors would care to admit), but could not regulate interrogation techniques. When lines must be drawn in the face of ambiguous text (and without resort to history), any particular line seems somewhat arbitrary.

Even if the last theory makes good policy sense, it might be way off, at least as a matter of the original understanding. We just cannot say which theory is right in the abstract. Until we do some difficult historical research about the original meaning of these various powers, all we can do is make somewhat educated guesses.

Far too many have avoided undertaking this research (the author included). Some scholars, it seems, have tended to leap to conclusions based on their policy preference. This seems particularly true of the Bybee memo's numerous critics. For many, the goal seems to be to bar the use of torture. Unless the Constitution bars the torturing of enemies (a proposition advanced by Dean Koh in his speech ${ }^{15}$ ), however, it would seem that the very arguments made by the Bybee memo's critics could be used to suggest that Congress could order U.S. soldiers to torture enemy combatants. If the power to regulate the armed forces and captures permits a ban on torture, why would not the same powers authorize Congress to require torture? More ominously, Congress might order soldiers "to take no prisoners"- to shoot all enemy soldiers-something the Constitution surely says nothing about one way or the other. ${ }^{16}$ If the policy goal is to bar all torture, trying to find some structural reason for why Congress's statutory prohibition of torture must trump the President's contrary preference simply will not establish a permanent and solid barrier to torture. Those who oppose torture must make sustained arguments about why the Constitution bars such wartime tactics, whoever might order it.

Arguments about the structural Constitution that seek to further a particular moral view are likely to be utterly feckless. Torture may be an evil necessary for the

gives us little reason to suppose that the President has more CINC power during wartime. The argument that the President must have exclusive control over the operations on a battlefield might be right, but it hardly arises from a clear implication of the text. More likely, it stems from a shared intuition that Congress should not be involved in day-to-day tactical decisions.

14. See id. at 39-41.

15. Dean Koh advanced this proposition in his speech, Harold Hongju Koh, Can the President Be Torturer in Chief?, 81 IND. L.J. 1145, 1157-60 (2006).

16. Presumably, all these things might be said of the Bybee memo's view of the CINC power as well. 
successful prosecution of war against Al-Qaeda, or an unspeakable act that benefits absolutely no one. Whatever it is, these difficult moral questions have little to do with whether the Constitution enables the President to order the use of coercive interrogation techniques in the face of a statute that prohibits such means. 